\title{
THERMOPHYSICAL BEHAVIOUR OF REINFORCED CONCRETES
}

\author{
Balázs Nagy ${ }^{1}$ \\ Dóra Szagri ${ }^{2}$
}

UDK: 666.973.6:536.2

DOI: 10.14415/konferencijaGFS2018.023

Summary: Nowadays, understanding thermophysical behaviour of reinforced concrete elements is important even in the field of structural engineering, because of the increasingly tightening building energy performance regulations and environmental awareness. Additionally, thermal behaviour plays a major role in fire resistance design and evaluation of structures. This paper presents a comparative analysis of the thermal properties of reinforced concretes. We have collected the thermophysical properties (thermal conductivity and diffusivity) from relevant and selected national standards and literature, and compared them with our laboratory measurement results on reinforced concretes and steel fibre reinforced concretes. During the study, we discuss the similarities and differences between various standards and literature, including the presentation of our experiments. This research could further contribute to the development of fire resistant reinforced concrete elements and environmentally conscious structural designs.

Keywords: Reinforced concrete, steel fibre, thermal conductivity, thermal diffusivity

\section{INTRODUCTION}

During practical structural design, energy efficiency has an increasing role. In building energy and fire resistance calculations it is essential to know the thermal properties of components. In building energy calculations, thermal conductivity values from MSZ EN ISO 10456:2008 [1] are mainly used, although the standard defines concrete's values only by taking into account the density and the approximate percentage of reinforcement, and the standard does not mention the properties of steel fibre reinforced concretes. In this research, we have measured the thermal properties of these materials including different designed reinforcements, and using variable amount of steel fibre. Results shows, that depending on the structure type, design and the amount of steel rebar or steel fibre content, there is a difference in the structure's equivalent thermal conductivity.

\footnotetext{
${ }^{1}$ Balázs Nagy, PhD candidate, MSc in Structural Engineering, Budapest University of Technology and Economics, Faculty of Civil Engineering, Department of Construction Materials and Technologies, Mủegyetem rkp. 3. K.I.85., H-1111, Budapest, Hungary, e - mail: nagy.balazs@epito.bme.hu

${ }^{2}$ Dóra Szagri, MSc student, Demonstrator, Budapest University of Technology and Economics, Faculty of Civil Engineering, Department of Construction Materials and Technologies, Müegyetem rkp. 3. K.I.85., H1111, Budapest, Hungary, e - mail: szagridora@edu.bme.hu
} 


\section{LITERATURE REVIEW}

Several literatures can be found in the topic of thermal properties of concretes, but these are mostly about the effect of type and amount of aggregates [2-4] or the effect of elevated temperatures $[5,6]$.

Analysing the reinforced concretes, it is visible, that the correlation between the bulk density and the thermal conductivity are fundamental, such as the relation between concrete's porosity and thermal properties. High density concretes and fibre reinforced concretes have thermal conductivity between $2.0-3.2 \mathrm{~W} / \mathrm{mK}$ at standard temperature according to several researches [3,7]. Some of these indicates, that increasing the amount of steel fibres used in concrete results always higher thermal conductivity [8].

These studies neglect the fact that the increased fibre content can increase the total porosity of the specimen as well [9], and it could result lower thermal conductivity values. In building energy calculations, a large number of experts are using withdrawn standards, e.g. MSZ 140/04-2:1991 [10]. The values of Table 1 show the main problem with this practice, we can find different values on thermal properties of concrete and reinforced concrete, and this difference is quite significant.

Table 1. Thermal conductivities of concretes and steels in standards.

\begin{tabular}{llcc}
\hline \multicolumn{1}{c}{ Standard } & \multicolumn{1}{c}{ Material } & $\begin{array}{c}\text { Density } \\
\boldsymbol{\rho}\left[\mathbf{k g} / \mathbf{m}^{\mathbf{3}}\right]\end{array}$ & $\begin{array}{c}\text { Thermal } \\
\text { conductivity } \\
\boldsymbol{\lambda}[\mathbf{W} / \mathbf{m K}]\end{array}$ \\
\hline \multirow{2}{*}{ MSZ 04-140/2:1991 } & reinforced concrete & 2400 & 1.55 \\
\cline { 2 - 4 } MSZ 24140:2015 & concrete & 2200 & 1.28 \\
\hline & reinforced concrete & 2400 & 2.5 \\
\cline { 2 - 4 } & concrete & 2200 & 2.0 \\
\cline { 2 - 4 } & $\begin{array}{l}\text { medium density } \\
\text { concrete }\end{array}$ & 2000 & 1.15 \\
\cline { 2 - 4 } MSZ EN ISO 10456:2008 & high density concrete & 2400 & 1.35 \\
\cline { 2 - 4 } & $\begin{array}{l}\text { reinforced concrete } \\
\text { (with 1\% of steel) }\end{array}$ & 2300 & 2.0 \\
\cline { 2 - 4 } & $\begin{array}{l}\text { reinforced concrete } \\
\text { (with 2\% of steel) }\end{array}$ & 2400 & 2.3 \\
\cline { 2 - 4 } & steel & 7800 & 50 \\
\hline
\end{tabular}

The operative MSZ EN ISO 10456:2008 [1] standard contains conversion factors of concretes. For accurate calculations we have to take into account the temperature, moisture and ageing conversion factors. Conversions of thermal values from one set of conditions $\left(\Theta_{1}, \psi_{1}\right)$ to another set of conditions $\left(\Theta_{2}, \psi_{2}\right)$ are carried out according to the following equations:

$$
\begin{gathered}
F_{\mathrm{T}}=\mathrm{e}^{\mathrm{f}_{\mathrm{T}}\left(\mathrm{T}_{2}-\mathrm{T}_{1}\right)} \\
\mathrm{F}_{\mathrm{m}}=\mathrm{e}^{\mathrm{f}_{\Psi}}\left(\Psi_{2}-\Psi_{1}\right) \\
\lambda_{2}=\lambda_{1} \cdot \mathrm{F}_{\mathrm{T}} \cdot \mathrm{F}_{\mathrm{m}} \cdot \mathrm{F}_{\mathrm{a}}
\end{gathered}
$$


Contemporary achievements in civil engineering 20. April 2018. Subotica, SERBIA

where $F_{T}, F_{m}$ are the conversion factors of temperature and moisture, $f_{T}$ is the temperature conversion coefficient, $\mathrm{f}_{\Psi}$ is the moisture conversion coefficient volume by volume which values are specific to the materials.

In case of concrete structures, $\mathrm{f}_{\mathrm{T}}=0.001 \mathrm{~K}^{-1}$ and $\mathrm{f}_{\Psi}=4 \mathrm{~m}^{3} \cdot \mathrm{m}^{-3}$. Ageing conversion factor $\mathrm{F}_{\mathrm{a}}$ is set to 1.0 by both the standard and the experts as well in the absence of detailed investigations of materials' ageing behaviour.

In Eurocode, the thermal conductivity of concrete and steel are given by the function of temperature (Fig. 1). The thermal conductivity of concrete should be between an upper and lower limit according to EN 1992-1-2:2013 [11], showed in eq.4 and eq.5, where $\theta$ is the temperature of concrete in centigrade:

$$
\begin{gathered}
\lambda_{\text {c,upper }}=2-0.2451 \cdot(\theta / 100)+0.0107 \cdot(\theta / 100)^{2} \\
\lambda_{\text {c,upper }}=1.36-0.136 \cdot(\theta / 100)+0.0057 \cdot(\theta / 100)^{2}
\end{gathered}
$$

The thermal conductivity of structural steel between $20^{\circ} \mathrm{C}$ and $800{ }^{\circ} \mathrm{C}$ according to EN $1993-1-2: 2013$ [12] is describable using eq. 6 . and constant 27.3 [W/mK] value between $800{ }^{\circ} \mathrm{C}$ and $1200{ }^{\circ} \mathrm{C}$.

$$
\begin{gathered}
\lambda_{\mathrm{s}}=54-0.0333 \cdot \theta_{\mathrm{s}}[\mathrm{W} / \mathrm{mK}] \\
\lambda_{\mathrm{s}, 800}=27.3[\mathrm{~W} / \mathrm{mk}]
\end{gathered}
$$
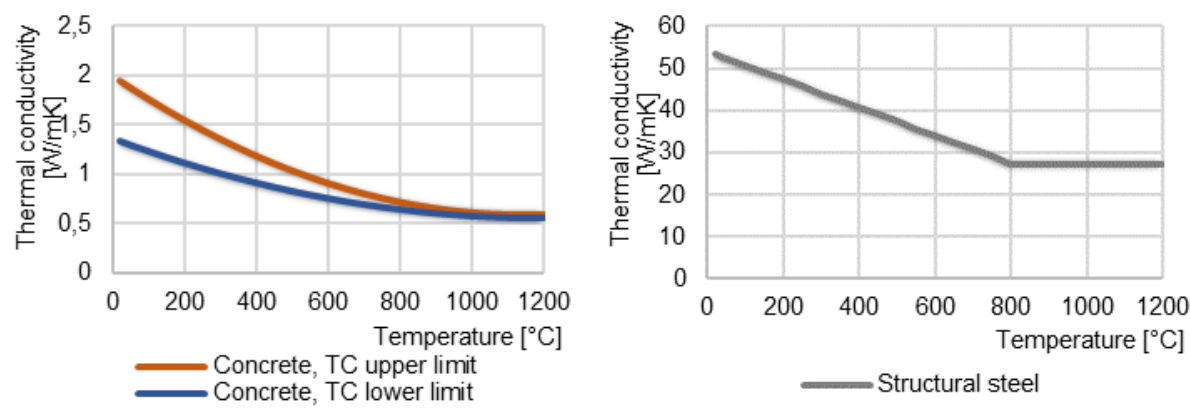

Figure 1. Thermal conductivity of concrete and structural steel according to Eurocode

Netherland's NBN B 62-002:2001 standard is also a notable standard, because it discusses the material properties depending on their condition.

The thermal conductivity values are grouped by their density and distinguished by internal and external sides, declaring the internal side at $23{ }^{\circ} \mathrm{C}$ and $50 \%$ and the external side at $10^{\circ} \mathrm{C}$ and $80 \%$.

These thermal conductivity values are close to the their real average application performance. 
Table 2. Thermal conductivity factors in NBN standards [13]

\begin{tabular}{lllcc}
\hline Standard & Denomination & $\begin{array}{c}\text { Density } \\
\boldsymbol{\rho}[\mathbf{k g} / \mathbf{m} 3]\end{array}$ & $\begin{array}{c}\text { Internal } \\
\text { thermal } \\
\text { conductivity } \\
\boldsymbol{\lambda}_{\text {Ui }}[\mathbf{W} / \mathbf{m K}]\end{array}$ & $\begin{array}{c}\text { External } \\
\text { thermal } \\
\text { conductivity } \\
\boldsymbol{\lambda}_{\text {Ue }}[\mathbf{W} / \mathbf{m K}]\end{array}$ \\
\hline \multirow{3}{*}{$\begin{array}{l}\text { NBN B 62- } \\
\text { 002:2001 }\end{array}$} & concrete & $2000-2100$ & 1.44 & 1.86 \\
\cline { 2 - 5 } & concrete & $2100-2200$ & 1.57 & 2.04 \\
\cline { 2 - 5 } & concrete & $2200-2300$ & 1.72 & 2.24 \\
\cline { 2 - 5 } & steel & 7800 & 45 & 45 \\
\hline
\end{tabular}

Czech national standard about material properties ČSN 730540-3:2005 [14] contains the thermal conductivities of many different concretes. The characteristic and design values are also available depending on the density. The standard's calculation method operates with moisture conversion coefficients to calculate the values according to the real situation. These values are in similar ranges like old Hungarian standard's [10] values.

Table 3. Thermal conductivity factors in the Czech National Standard [14].

\begin{tabular}{|c|c|c|c|}
\hline Standard & Material & $\begin{array}{c}\text { Density } \\
\rho\left[\mathrm{kg} / \mathrm{m}^{3}\right]\end{array}$ & $\begin{array}{l}\text { Design thermal conductivity } \\
\qquad \lambda[\mathrm{W} / \mathrm{mK}]\end{array}$ \\
\hline \multirow{7}{*}{ ČSN 730540-3:2005 } & \multirow{3}{*}{ concrete } & 2100 & 1.23 \\
\hline & & 2200 & 1.30 \\
\hline & & 2300 & 1.36 \\
\hline & \multirow{3}{*}{$\begin{array}{l}\text { reinforced } \\
\text { concrete }\end{array}$} & 2300 & 1.43 \\
\hline & & 2400 & 1.58 \\
\hline & & 2500 & 1.74 \\
\hline & steel & 7800 & 58 \\
\hline
\end{tabular}

\section{CONCRETE SPECIMENS}

In the recent years, we tested different concrete and reinforced concrete samples in our laboratory of building physics [15-18]. In this paper, we introduce the results of steel fibre reinforced and reduced aspect ratio reinforced concrete slab experiments.

For laboratory measurements of thermal conductivity of concrete slabs, we have made different specimens. For the reinforced concrete, we have performed a 1:2 scale miniature element of slabs with different diameters of bars. For the steel fibre reinforced concrete Humix 50 cold formed steel fibres were used with different amount $\left(20 \mathrm{~kg} / \mathrm{m}^{3}-\right.$ $27.5 \mathrm{~kg} / \mathrm{m}^{3}-35 \mathrm{~kg} / \mathrm{m}^{3}$ ). Each concrete mixture was distributed to six standard 15x15x15 $\mathrm{cm}$ cubes and three 20x20x10 cm cuboids because of the capability of our Taurus TLP 300 DTX thermal conductivity measuring device. We have designed the reinforced slabs with $4 \mathrm{~mm}, 5 \mathrm{~mm}$, and $6 \mathrm{~mm}$ reinforcement bar diameter, according to the reduced aspect ratio the maximum ratio of the additive grain size was halved $\left(\mathrm{d}_{\mathrm{max} \text {,original }}=16\right.$ $\mathrm{mm}$, while $\mathrm{d}_{\text {max,reduced }}=8 \mathrm{~mm}$ ). The specimens made for thermal conductivity measurements were stored in water for 7 days, then stored in a temperature and humidity conditioning chamber at $23{ }^{\circ} \mathrm{C}$ and $50 \% \mathrm{RH}$. 
Contemporary achievements in civil engineering 20. April 2018. Subotica, SERBIA

\section{THERMAL CONDUCTIVITY MEASUREMENT}

The steel fibre reinforced specimens were tested once after the conditioning with still moist samples and once after one year of storing them in laboratory conditions, therefore the specimens dried out naturally.

The reinforced samples were measured after their conditioning phase, but the samples were dried out artificially before the measurements.

Thermal conductivity was measured using a Taurus TLP 300 DTX guarded hot plate instrument (see Fig. 2.) according to MSZ EN 12664:2001 [19]. Before the thermal conductivity measurement, the hardened concrete's density was measured according to MSZ EN 12390-7:2009 [20]. During measurements, laboratory air temperature was set to $23 \pm 2{ }^{\circ} \mathrm{C}$ and the relative humidity was between $45-55 \% \mathrm{RH}$.

The specimens were framed using $10 \mathrm{~cm}$ thick EPS foam stocks, ensuring that the temperature or humidity in the lab do not affect the results of the measurements and in the specimens measured intermediate $10 \times 10 \mathrm{~cm}$ area, one-dimensional steady state heat flow can develop during all three measured temperature stages.

The stages were set to $5 / 15^{\circ} \mathrm{C}, 15 / 25^{\circ} \mathrm{C}$ and $25 / 35^{\circ} \mathrm{C}$ and the tests ended when relative error in thermal conductivity was under $0.2 \%$. The results are given in Table 4 .
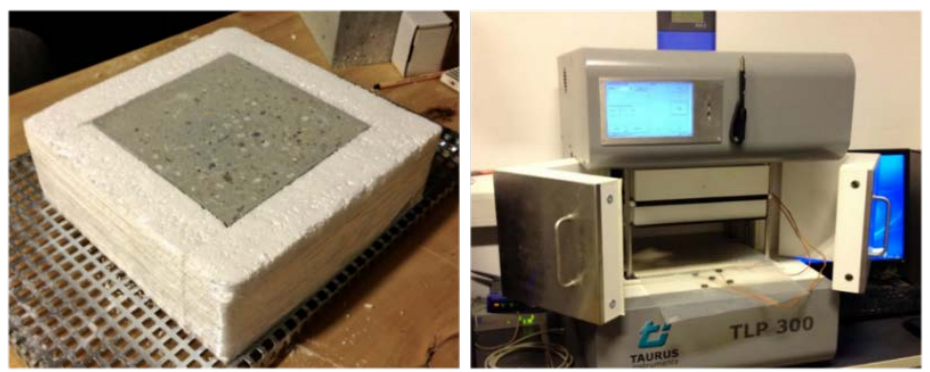

Figure 2. EPS framed concrete specimen, Taurus TLP 300 DTX guarded hot plate measuring instrument

Table 4. Results of thermal conductivity measurements

\begin{tabular}{llcc}
\hline \multirow{2}{*}{ Type } & Name & $\begin{array}{c}\text { Measured TC after 28 days } \\
\text { moist samples @ 23 }{ }^{\circ} \mathbf{C} \\
\lambda[\mathbf{W} / \mathbf{m K}]\end{array}$ & $\begin{array}{c}\text { Measured TC of dried } \\
\text { samples @ 23 } \\
{ }^{\circ} \mathbf{C}\end{array}$ \\
\hline \multirow{2}{*}{$\begin{array}{l}\text { steel fibre } \\
\text { reinforced } \\
\text { concrete }\end{array}$} & $\mathrm{REF}$ & 1,79 & 1,68 \\
\cline { 2 - 4 } & $\mathrm{S} 35$ & 1,87 & 1,75 \\
\cline { 2 - 4 } & $\mathrm{S} 27,5$ & 2,11 & 1,99 \\
\cline { 2 - 4 } reinforced & $\mathrm{S} 20$ & 2,16 & 2,03 \\
\cline { 2 - 4 } concrete & $\mathrm{REF}$ & - & 1,46 \\
\cline { 2 - 4 } & $\mathrm{P} 1-6 \mathrm{~mm}$ & - & 1,47 \\
\cline { 2 - 4 } & $\mathrm{P} 2-5 \mathrm{~mm}$ & - & 1,48 \\
\hline
\end{tabular}


Савремена достигнућа у грађевинарству 20. април 2018. Суботица, СРБИЈА

Results shows that steel fibre reinforced concretes had higher thermal conductivity compared to reinforced concretes and it is observable, that the reference samples had lower thermal conductivity values.

Reinforcement bars in concrete only slightly changed the thermal conductivity, because there was enough "insulating" concrete covering over the reinforcement. Randomly oriented steel fibres however could increase the thermal conductivity of a concrete sample by up to $20 \%$. It is eye-catching, that once steel fibres is used, when the amount of steel fibre is increased (e.g. from $20 \mathrm{~kg} / \mathrm{m}^{3}$ to $35 \mathrm{~kg} / \mathrm{m}^{3}$ ), thermal conductivity is decreased.

This phenomena is occurring because additional fibres change the concrete's density and porosity [15]. The measured values remained below the MSZ EN ISO 10456:2008 [1] standard values, but we should highlight that the density of concrete, the concrete mixture or the porosity can greatly influence the thermal conductivity.

\section{THERMAL DIFFUSIVITY}

Besides the thermal conductivity measurements, we measured the specimens' bulk density [20] and specific heat capacity using mixing calorimetry [15].

From these properties, thermal difussivity can be calculated using eq. 8:

$$
\mathrm{a}=\lambda /\left(\rho \cdot \mathrm{C}_{\mathrm{p}}\right)\left[\mathrm{m}^{2} / \mathrm{s}\right]
$$

Thermal diffusivity measures the rate of heat transfer in a material, and is mandatory to know for transient heat transfer calculations, such as calculating the reinforced concrete structure's momentary temperatures in fire resistance design.

Concrete and steel thermal diffusivity is shown in figure 3. calculated from Eurocode material properties between $20^{\circ} \mathrm{C}$ to $1200{ }^{\circ} \mathrm{C}$. The functions of the concrete shows lower and upper limit of thermal diffusivity of concrete, depending on it's mass by mass moisture content (u\%).
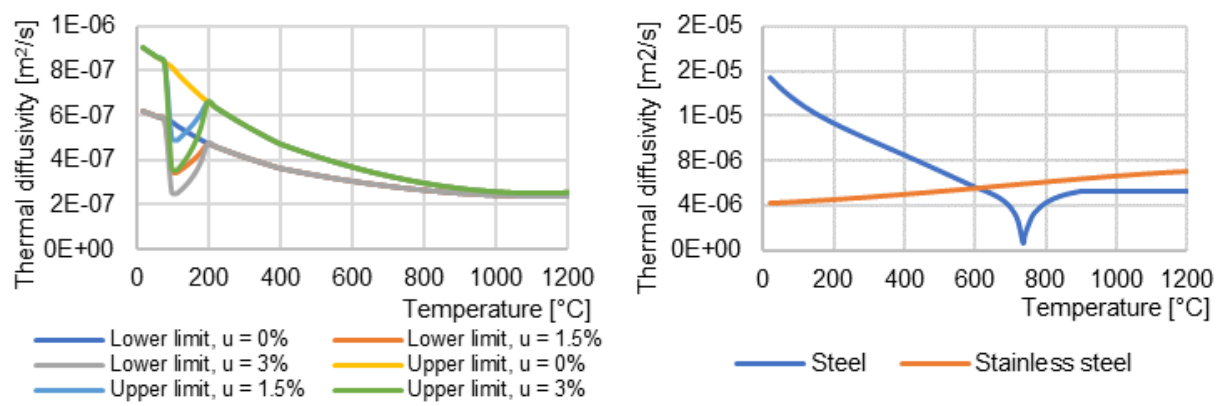

Figure 3. Thermal diffusivity of concrete and steel according to Eurocode

Our measured values are summarized in table 5. comparing to the values calculated from MSZ EN ISO 10456:2008 [1] standard's data. 
$6^{\text {th }}$

INTERNATIONAL CONFERENCE

Contemporary achievements in civil engineering 20. April 2018. Subotica, SERBIA

Table 5. Thermophysical properties of reinforced concretes

\begin{tabular}{|c|c|c|c|c|c|}
\hline Type & Sample & $\begin{array}{c}\text { Density } \\
\rho\left[\mathrm{kg} / \mathrm{m}^{3}\right]\end{array}$ & $\begin{array}{c}\text { Specific heat } \\
\text { capacity } \\
C_{p}[\mathrm{~J} / \mathrm{kgK}]\end{array}$ & $\begin{array}{c}\text { Thermal } \\
\text { conductivity } \\
\lambda[\mathrm{W} / \mathrm{mK}]\end{array}$ & $\begin{array}{c}\text { Thermal } \\
\text { diffusivity } \\
{\left[\cdot 10^{-7} \mathrm{~m}^{2} / \mathrm{s}\right]}\end{array}$ \\
\hline \multirow{4}{*}{$\begin{array}{l}\text { steel fibre } \\
\text { reinforced } \\
\text { concrete }\end{array}$} & REF & 2401 & 880 & 1.68 & 7.95 \\
\hline & S35 & 2429 & 873.8 & 1.75 & 8.25 \\
\hline & $\mathrm{S} 27,5$ & 2419 & 875.1 & 1.99 & 9.40 \\
\hline & S20 & 2414 & 876.4 & 2.03 & 9.59 \\
\hline \multirow{4}{*}{$\begin{array}{l}\text { reinforced } \\
\text { concrete }\end{array}$} & REF & 2280 & 880 & 1.46 & 7.28 \\
\hline & P1 - 6mm & 2311 & 874.2 & 1.47 & 7.28 \\
\hline & $\mathrm{P} 2-5 \mathrm{~mm}$ & 2315 & 886.8 & 1.48 & 7.21 \\
\hline & $\mathrm{P} 4-4 \mathrm{~mm}$ & 2306 & 885.2 & 1.48 & 7.25 \\
\hline \multirow{2}{*}{$\begin{array}{l}\text { MSZ EN } \\
\text { ISO } 10456\end{array}$} & $\begin{array}{l}\text { Reinforced } \\
2 \% \text { steel }\end{array}$ & 2400 & 1000 & 2.5 & 10.40 \\
\hline & $\begin{array}{l}\text { Reinforced } \\
1 \% \text { steel }\end{array}$ & 2300 & 1000 & 2.3 & 10.00 \\
\hline
\end{tabular}

\section{NUMERICAL SIMULATIONS}

In case of 3D simulations two different methods were carried out. Our first target was to model and predict the thermal conductivity of concretes with different amount of randomly oriented steel fibres in it. To determine the average content of the mixtures, 50 randomly chosen steel fibres weighted with an average of $0.304 \mathrm{~g}$. After modelling the steel fibre itself (see Fig. 4.), we have multiplied and placed them randomly oriented according that the S20 mixture steel fibre content was 264 pieces; for the S27.5 mixture, 362 pieces and for the S35 mixture 461 pieces of steel fibres were needed.
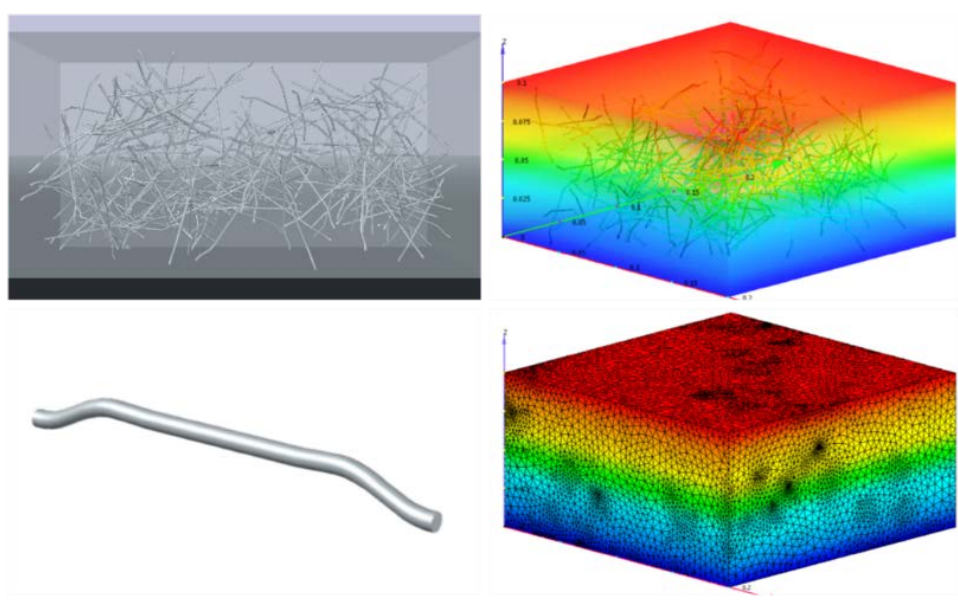

Figure 4. Steel fibre reinforced concrete simulation model and temperature distributions 
Савремена достигнућа у грађевинарству 20. април 2018. Суботица, СРБИЈА

$\mathrm{n}$ reality, the actual volume of steel fibres in a specimen may be different compared to the above, depending on the concreting process. In the simulation, 5 different randomly oriented models were made for each mixture.

The thermal conductivity of steel fibres was set to $55 \mathrm{~W} / \mathrm{mK}$ and the equivalent thermal conductivity of concrete was iterated and chosen to get the measured thermal conductivities of each sample. Therefore, the simulation was calibrated by the concrete's thermal conductivity.

The boundary conditions were $20^{\circ} \mathrm{C}$ and $0{ }^{\circ} \mathrm{C}$ on sides without surface resistance. After retrieving heat flows from the surface, the thermal conductivity of the sample was calculated.

Table 6. Results of the calibrated simulations

\begin{tabular}{cccccc}
\hline Samples & $\begin{array}{c}\text { Steel fibres } \\
\left(\mathbf{k g} / \mathbf{m}^{3} \mathbf{)}\right.\end{array}$ & $\begin{array}{c}\text { Measured } \\
\text { TC } \\
{[\mathbf{W} / \mathbf{m K}]}\end{array}$ & $\begin{array}{c}\text { Steel TC } \\
\text { [W/mK] }\end{array}$ & $\begin{array}{c}\text { Eqv. concrete } \\
\text { TC } \text { [W/mK] }\end{array}$ & $\begin{array}{c}\text { Simulated } \\
\text { avg. TC } \\
\text { [W/mK] }\end{array}$ \\
\hline S1 & 35 & 2.86 & 55 & 2.78 & 2.86 \\
\hline S2 & 27.5 & 2.85 & 55 & 2.80 & 2.85 \\
\hline S3 & 25 & 2.97 & 55 & 2.93 & 2.97 \\
\hline
\end{tabular}

In case of reinforced concrete, the thermal conductivity of concrete was set to $2 \mathrm{~W} / \mathrm{mK}$ and $60,5 \mathrm{~W} / \mathrm{mK}$ was used for structural steel. The boundary conditions were $15^{\circ} \mathrm{C}$ and 5 ${ }^{\circ} \mathrm{C}$ on the opposite sides of the modelled specimens.

Running this type of simulation demands high computing power, therefore we had to make some simplifications in the model (Fig. 5.). One of this was the geometric simplification of the reinforcing bars, in which we studied the replacement geometry of the real reinforcing steel bars according to MSZ EN 10080:2005 [21] in the case of octagonal-based prism.

Models with this octagonal-based prism showed less than $1 \%$ difference, however both FE mesh and running time is reduced dramatically thank to the simplification.
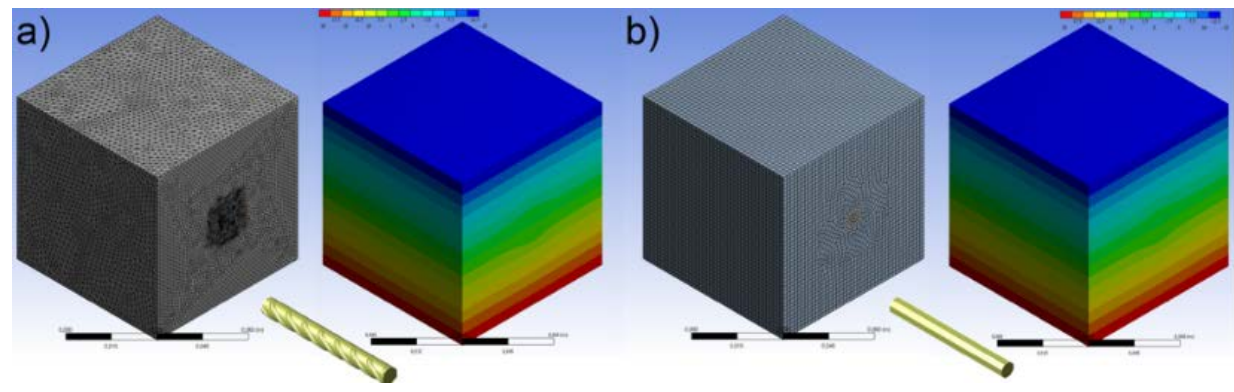

Figure 5. Effects of simplification of reinforcing bars on FE mesh and temperature distribution: a) real geometry; b) octagonal-based prism simplified geometry 
Contemporary achievements in civil engineering 20. April 2018. Subotica, SERBIA

In addition, we have studied the case of leaving out the rebar spacers (stays) from the slabs, which can save significant calculation time too. The tests demonstrated (Fig. 6.) that in the case of neglecting stays, the heat fluxes on the boundaries does not affected significantly, the difference is less than $1.5 \%$, but only if at least $10 \mathrm{~mm}$ concrete covering was used.

The Eurocode recommends to apply at least $25 \mathrm{~mm}$ concrete coverings on slabs, therefore this simplification will not affect the results, the concrete cover is practically isolate the stays from the external environment.

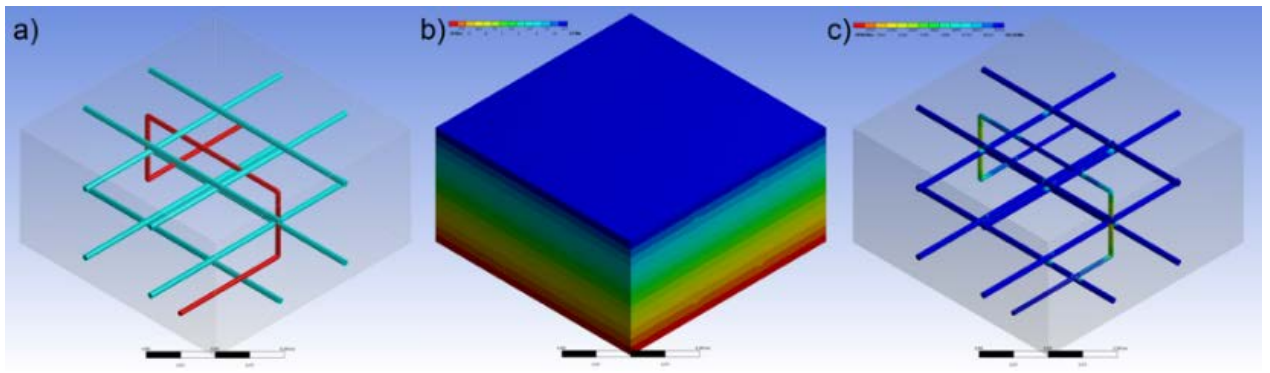

Figure 6. The effects of rebar spacers: a) FE mesh, b) temperature distribution, c) heat flux densities in steel reinforcement bars and stays

We have designed six different $6 \mathrm{~m} \times 6 \mathrm{~m} \times 0.2 \mathrm{~m}$ roof slab parts using different diameters $(8 \mathrm{~mm}, 10 \mathrm{~mm}$ and $12 \mathrm{~mm})$ for the reinforcement bars. After evaluating of results, we stated that in the case of slabs, the distribution of the rebars are not alternate significantly the thermal conductivity of the concrete slab. In any case, the difference between the heat fluxes was below $2 \%$.

However, we can see connection between the placed amount of reinforcement bars and the heat fluxes, even if the difference is insignificant. Solid reinforced concrete slabs can be modelled using concrete's thermal properties only.

\section{SUMMARY}

We reviewed European Standards on thermal conductivities of concrete, reinforced concrete and steel, and this paper shows that there is substantive difference between the measured thermal conductivities and the standard's values. In case of steel fibre reinforced concretes increasing the amount of steel fibre does not necessarily increase the thermal conductivity.

Using numerical simulations, we could model the thermal conductivity values with any amount of fibres or reinforcement bars in a specified range. Reinforced concrete slabs can be modelled using only the concrete's thermophysical properties if the mandatory minimum concrete covering is applied. 
6. МЕЂУНАРОДНА КОНФЕРЕНЦИЈА

Савремена достигнућа у грађевинарству 20. април 2018. Суботица, СРБИЈА

After we measured and simulated specimens of bar reinforced concretes, we showed that the measured values are different than the operative standard's, but similar to the Czech or old Hungarian standard's values. Opposed to this, fibre reinforced concretes have significantly different thermophysicsal properties compared to reference concretes. In conclusion with the measurements and simulations, in the field of building physics and energy design we are able to calculate more accurately the reinforced concrete's thermal behaviour knowing their thermophysical behaviour.

\section{REFERENCES}

[7] MSZ EN ISO 10456:2008, Building materials and products. Hygrothermal properties. Tabulated design values and procedures for determining declared and design thermal values (ISO 10456:2007), MSZT, Budapest, 2008.

[8] Damdelen, O., Georgopoulos, C., Limbachiya, M.C., Measuring thermal mass of sustainable concrete mixes, Computing in Civil and Building Engineering, 2014., p.p. 1554-1561.

[9] Howlader, M.K., Rashid, M.H., Mallick, D., Hawue, T., Effects of aggregate types on thermal properties of concrete, ARPN Journal of Engineering and Applied Sciences, 2012., vol 7, p.p. 900-906

[10]Dügenci, O., Haktanir, T., Altun, F., Experimental research for the effect of high temperature on the mechanical properties of steel fiber-reinforced concrete, Construction and Building Materials, 2015., vol. 75, p.p. 82- 88.

[11]Kodur, V., Properties of concrete at elevated temperature. ISRN Civil Engineering, 2014., p.p. 1-15.

[12] Khaliq W, Kodur ,V., Thermal and mechanical properties of fiber reinforced high performance self- consolidating concrete at elevated temperatures, Cement and Concrete Research, 2011., vol. 41.

[13]Cook, D.J., Uher, C., The thermal conductivity of fibre-reinforced concrete, Cement and Concrete Research, 1974., vol. 4, p.p. 497-509.

[14] Tinker, J.A., Cabrera, J.G., Modeling the thermal conductivity of concrete based on its measured density and porosity. Buildings V. Conference proceedings, 1992., p.p. 91-95.

[15] Nehme SG. Porosity of concrete. PhD thesis; Dept. of Civil Eng. Budapest University of Techology and Economics; 2004.

[16] MSZ 04-140-2:1991, Power Engineering Dimensioning Calculuses of Buildings and Building Envelope Structures, KTM, Budapest, 1991.

[17] MSZ EN 1992-1-2:2013, Eurocode 2: Design of concrete structures. Part 1-2: General rules. Structural fire design, MSZT, Budapest, 2013.

[18] MSZ EN 1993-1-2:2013, Eurocode 3: Design of steel strucutures. Part 1-2: Strucutural fire design, MSZT, Budapest, 2013.

[19] Hens, H., Applied Building Physics, Boundary Conditions, Building Performance and Material Properties, Wilhelm Ernst \& Sohn, Berlin, 2011.

[20] ČSN 73 0540-3:2005, Thermal protection of buildings - Part 3: Design value quantities, Czech Office for Standards, Metrology and Testing, Prague, 2015.

[21] Nagy, B., Nehme, S.G., Szagri, D., Thermal properties and modeling of fiber reinforced concretes, Energy Procedia, 2015., vol. 78, p.p. 2742-2747. 


\section{$6^{\text {th }}$}

Contemporary achievements in civil engineering 20. April 2018. Subotica, SERBIA

[22] Nagy, B., Szagri, D., Hygrothermal properties of steel fiber reinforced concretes, Applied Mechanics and Materials, 2016., vol. 824, p.p. 579-588.

[23] Nagy, B., Paulik, E., Reinforcement-Dependent Thermal Properties of Reinforced Concrete Columns and Slabs, Applied Mechanics and Materials, 2016., vol. 861, p.p. 279-286.

[24] Orosz, M., Nagy, B., Tóth, E., Hygrothermal behaviour of ultra-lightweight polystyrene concrete, Pollack Periodica, 2017., vol. 12, № 2, p.p. 53-66.

[25] MSZ EN 12664:2001 Thermal performance of building materials and products. Determination of thermal resistance by means of guarded hot plate and heat flow meter methods. Dry and moist products of medium and low thermal resistance, MSZT, Budapest, 2001.

[26] MSZ EN 12390-7:2009 Testing hardened concrete. Part 7: Density of hardened concrete, MSZT, Budapest, 2009.

[27] MSZ EN 10080:2005, Steel for the reinforcement of concrete. Weldable reinforcing steel. General requirements, MSZT, Budapest, 2015. 